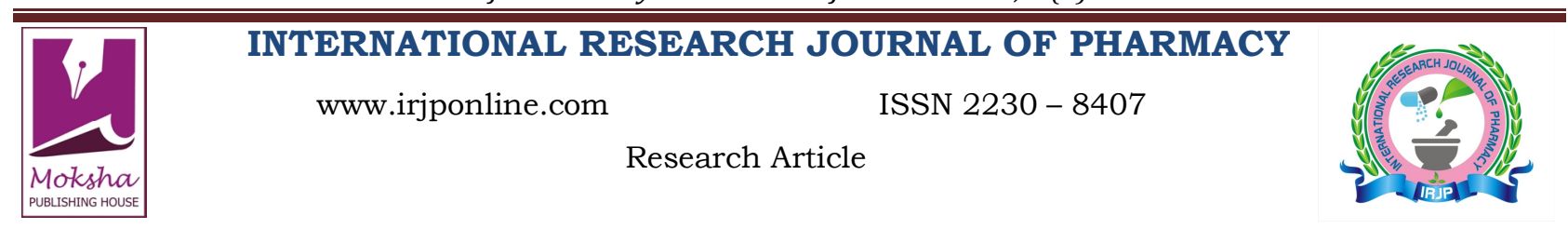

\title{
COMPARATIVE STUDY ON THE SUBSTITUTES USED IN AYURVEDA WITH SPECIAL REFERENCE TO SUBSTITUTES FOR PUSHKARAMULA (INULA RACEMOSA HOOK.F.) VIZ., KUSHTA (SAUSSUREA LAPPA DECNE.) AND ERANDAMULA (RICINUS COMMUNIS L.): A CLINICAL STUDY \\ J. L. N. Sastry ${ }^{1}$, Tanuja M. Nesari ${ }^{2}$, Huparikar Rajendra ${ }^{3}$ \\ ${ }^{1}$ Dabur-Dhanwantry Hospital, Sector 46 B, Chandigarh, India \\ ${ }^{2}$ P.G. Dept. of Dravyaguna, Tilak Ayurveda Mahavidyalaya, Pune, Maharashtra, India \\ ${ }^{3}$ Dept.of Kayachikitsa \& Panchakarma, Tarachand Hospital, Pune, Maharashtra, India \\ Email: Lnsjata@yahoo.com
}

Article Received on: 16/03/13 Revised on: 08/04/13 Approved for publication: 13/05/13

DOI: $10.7897 / 2230-8407.04519$

IRJP is an official publication of Moksha Publishing House. Website: www.mokshaph.com

(C) All rights reserved.

\section{ABSTRACT}

Ayurvedic literature introduced several substitutes for the herbs which are either not available or which are not accessible for various reasons. On review of more than 35 texts and their commentaries it is found that there are more than 350 substitutes in the Ayurvedic texts from ancient to modern times. Kustha is known to therapeutics since Vedic period (2000 BC). Puskaramula and Erandamula were introduced to Ayurvedic Materia Medica by Agnivesa (500 BC). While mentioning the substitutes of Pushkaramula, Yogaratnakara quoted Kushta and Erandamula as the substitutes. Earlier author studied the pharmacognostical similarities between the three plants. Therefore, in the present study it iss decided to conduct a comparative study using the root powders of these three herbs in subjects $(\mathrm{n}=90)$ suffering with Tamaka Swasa (Bronchial Asthma) divided into three groups. The results are suggestive that all the trial herbs have comparable therapeutic benefits in the subjects of Tamaka Swasa. While Kustha and Puskaramula have chemical as well as therapeutic similarity, Erandamula and pushkaramula shared only therapeutic similarity though chemically dissimilar. Thiss paper emphasizes the need for the identification of cost effective substitutes basing on the text in place of endangered or extinct medicinal plants.

Key Words: Pushkaramula; Kushta EM = Erandamula

\section{INTRODUCTION}

'Ayurveda' - the knowledge of life sciences is full in medical knowledge. The chronology of Samhita granthas, Sangraha granthas, Yoga granthas and Nighantu granthas reflect the Ayurveda of respective times. On careful review we come across gradual increase in number of herbs used. In the process of adding new herbs, some confusion is also added in the form of multiple synonyms, multiple varieties etc. This has led to the controversy in the identity of some herbs. More over, migration of Vaids from forest areas to the urban areas resulted in dependancy upon shepherds and forest dwellers etc for the medicinal plants. Later, the controversy increased because, various people dwell in different areas with different cultures might have used the same name to denote different herbs. Thenceforth, substitutes as well as controversial herbs made their way into traditional practice. Where ever there is an availability issue or a cost issue, physicians were trying for suitable alternative.

Seers like Bhavamisra (16 AD) and Yogaratnakara (17 AD) did try to establish the comprehensive list of substitutes (Abhavapratinithi Dravyas or Alabdhapratinithi Dravyas) along with certain guidelines for substitution. However, in the present scenario (2005) Prevention of Food Adulteration Act 1954 considers substitute as the sysnonym for adulterant. For example, usage of Carum carvi for Cuminum cyminum or vice versa will attract the charges of Adulteration/Substitution. Therefore the author prepared a comprehensive data-base on the substitutes delineated in the Ayurvedic Texts ${ }^{1}$ and decided to study the comparative clinical effects at least one original herb vs substitute(s). Hence the present study on the comparative clinical efficacy of the substitutes for Puskaramula / PM (Inula recemosa Hook. f.) viz., Kushta / KS (Saussurea lappa (Decne.) C.B.Clarke.) and Erandamula / EM (Ricinus communis L.) ${ }^{26}$. Author earlier studied and reported the chemical similarity between PM (Inula racemosa Hook. f.) and KS (Saussurea lappa $\mathrm{CB}$ Clarke) ${ }^{2}$. It is also noted that Yogaratnakara mentioned both KS and EM as substitutes for PM. But, EM (Ricinus communis Linn.) neither has chemical similarity nor therapeutic similarity with PM. Therefore, it is decided to find out the comparative therapeutic benefits of these three herbs in a common indication like Tamaka Swasa (Bronchial Asthma) to test the concept of substitution. The comparative properties of the three trial herbs are provided in the table 1a.

Review of literature on the pharmacological similarities of trial herbs

The similarity in the pharmacological activity of the trial herbs is provided in Table $1 \mathrm{~b}$. All the three herbs have a common activity i.e., anti-inflammatory activity.

\section{Review of Disease (Asthma) literature}

Asthma is defined as a chronic inflammatory disorder of the airways characterized by reversible airflow obstruction causing cough, wheeze, tightness in the chest and breathlessness. Asthmatics fall between the ranges of 100 to 150 million people around the globe. The highest prevalence is reported from China and Malaysia. Worldwide deaths from this condition have reached over 180,000 annually. As per WHO Fact sheets, India has an estimated 15-20 million of asthmatics. $^{13}$

It is estimated that, $2.5 \%$ of adults have a clinical diagnosis of asthma. In case of children, the asthma figures rose to $15 \%$ with an episode of wheezing characteristic within the previous year, $5 \%$ of them diagnosed as suffering from asthma, $1 \%$ with severe disabling asthma. It is useful to classify asthma as early-onset or extrinsic asthma, which occurs usually in atopic children and resolves in $80 \%$. Lateonset asthma or idiopathic non-atopic adult asthma is chronic in the majority of cases. ${ }^{12}$ 
It is produced by the inflammation of the bronchial wall involving eosinophils, mast cells and lymphocytes, together with the cytokine and inflammatory products of these cells, inducing hyper-sensitiveness of the bronchi so that they narrow more readily in response to a wide range of stimuli. In brief, asthma may be described as presenting with either of the following three stages viz., air limitation, air-way hyperresponsiveness \& airway inflammation.

The principles for the management of patients with asthma, according to the guidelines of British Thoracic Society and International Consensus Report on the Diagnosis and Management of Asthma is as follows:

- Avoidance - measures to be taken to prevent/ reduce exposure to allergic agents.

- Hyposensitisation - subcutaneous injection of extracts of allergens (single allergen only). This form of therapy has largely been banned in Britain.

\section{Management of Chronic persistent asthma}

Inhaled corticosteroids are the most effective and widely used form of anti-inflammatory therapy for use in patients with asthma. Metered Dose Inhaler (MDI) is widely used technique to administer the bronchodilators or corticosteroids. In spite of different drugs and measures, neither there is a single oral agent, which will reduce the frequency of asthma attacks/ episodes nor an effective nonsteroidal respiratory anti-inflammatory drug in the modern pharmacology.

On the other hand it is noticed that several traditional / indigenous herbal drugs are being successfully used in the management of bronchial asthma and are found to be of some definite advantage viz.,

- Avoidance of side-effects of corticosteroids

- Enhancement of immunity

- Relief from symptoms/ frequent episodes for a longer time.

- Better compliance.

Ayurvedic texts quoted Bronchial Asthma as Svasa or Tamakasvasa. This condition is denoted as a result of exposure to dust, clouds etc along with other causative factors. This is caused by vata obstructed by kapha in the pranavaha srotas. Tamakasvasa if associated with fever is called as Pratamaka while without fever is called as Samtamaka i.e., Chronic Bronchitis and Chronic Allergic Bronchial Asthma respectively. This condition is claimed to be yapya according to Caraka. The treatment includes Virecana and Nasya under Sodhana procedures. Several Samana dravyas like Yastimadhu, Vasa, Kantakari, Puskaramula, kustha etc were found in the texts.

\section{MATERIAL \& METHODS}

The powdered samples of the roots of Pushkaramula (Inula racemosa), Kushta (Saussurea lappa) and Erandamula (Ricinus communis) have formed the materials for the study while 90 subjects (divided into 30 subjects in each group) suffering from Tamaka Swasa (Bronchial Asthma) have formed the subjects [in the age group of 16-65 years] of the present study.

\section{Aims \& objectives of the study}

Primary - To evaluate the comparative efficacy of Puskaramula and its substitutes Kustha and Erandamula in the management of Tamakasvasa (Bronchial Asthma).
Secondary - Symptomatic relief from Bronchial Asthma \& Clinical improvement in the condition of the patients after using the trial drugs for 12 weeks.

\section{Study Design}

- Open, Labeled, comparative, Randomized

- Prospective clinical trial

\section{Subject recruitment and screening}

Study Subjects - Mild to moderate Chronic Allergic Bronchial Asthma (NAEPP1997 revised guidelines) Subjects belonging to both the sex.

Recruitment The Subjects were recruited from the OPD of Sri Dhanwantary Ayurvedic College \& Hospital, Chandigarh and SethTarachand Hospital, Pune.

\section{Inclusion \& Exclusion criteria for study subjects Inclusion criteria}

- Subjects having mild to moderate Chronic Allergic Bronchial Asthma (NAEPP 1997 revised guidelines) belonging to both sex (atopic \& non-atopic) are eligible.

- Subjects capable of understanding and signing an informed consent.

- Subjects between 16 to 65 years.

- Subjects medically stable and with normal LFT, RFT and Haemogram values.

- Subjects should not be in acute attack of Bronchial Asthma.

\section{Exclusion criteria}

- Subjects suffering from very severe/very chronic form of asthma

- Subjects with concurrent pulmonary disease (pulmonary hypertension, cystic fibrosis, sarcoidosis, bronchiectasis, hypersensitivity pneumonitis, restrictive lung disease etc.)

- Pregnant or Lactating mothers and females planning to get conceived in near future.

- Subjects suffering from any psychological condition that will influence the conduct of the study or interpretation of results.

- Subjects with systemic diseases, like diabetes mellitus, venereal diseases and HIV.

- Subjects not willing to sign informed consent

- Subjects not willing to come for follow-up when required

- Subjects participating in any other clinical trials.

Therapeutic or Clinical end points

Therapeutic End Points: Treatment with the trial drugs for 12 weeks with or without improvement in the clinical condition of trial subjects.

\section{Clinical End Points}

- Relief of symptoms of Bronchial Asthma.

- Decrease in the frequency of attack.

- Decrease in the background modern medicines like Bronchodilators/steroids.

\section{Dosage Schedule}

All the trial drugs were given in a dose of $2.5 \mathrm{~g}$ b.i.d. (with or without modern standard $\mathrm{Tt}$ ) with honey thrice in a day. 


\section{Parameters for the Assesment of safety \& efficacy Safety parameters LFT, RFT, Haemogram}

\section{Efficacy parameters}

Subjective

- Global Asthma Control Score

- QoL assessment
- VAS score (subject as well as physician evaluation)

- Assessment symptoms of Asthma (viz., dyspnoea, cough \& wheezing)

Objective

- $\operatorname{IgE}$

- AEC

- Spirometry

Table 1a: Properties of trial drugs ${ }^{26}$

\begin{tabular}{|c|c|c|c|}
\hline Properties & Puskaramula & Kustha & Erandamula \\
\hline Rasa & Katu, Tikta & & Katu, Tikta \\
\hline Guna & Usna, Tiksna, Laghu, Snigdha & & Usna, Tiksna, Laghu, Snigdha \\
\hline Virya & Usna & Usna & Usna \\
\hline Vipaka & Katu & Katu & Katu \\
\hline Prabhava & Hrdya & Vrsya & Vrsya \\
\hline Karma & $\begin{array}{l}\text { Kapha-vatahara, Hikkanigrahana, Svasahara, } \\
\text { Kasahara, Jvarahara, Sophaghna }\end{array}$ & $\begin{array}{l}\text { Vata-kaphahara, Kusthaghna, Sukrala, } \\
\text { Kanduhara, Svasahara, Rasayana }\end{array}$ & $\begin{array}{c}\text { Kapha-vatahara, Jvarahara, } \\
\text { Sophaghna }\end{array}$ \\
\hline Indications & $\begin{array}{c}\text { Hricchula, Hrdroga, Parsvasula, Hikka, } \\
\text { Svasa, Kasa, Sotha \& Jvara }\end{array}$ & $\begin{array}{c}\text { Vatarakta, Visarpa, Kushta, Swasa, } \\
\text { Kasa, Vataroga }\end{array}$ & Vataroga, Sotha, Jvara \\
\hline Part used & Root (Mulam) & Root (Mulam) & Root (Mulam) \\
\hline Dosage & $2.5-5 \mathrm{~g}$ of powder & $2.5-5 \mathrm{~g}$ of powder & $2.5-5 \mathrm{~g}$ of powder \\
\hline Anupana & Honey & Honey & Honey \\
\hline
\end{tabular}

Table 1b: Pharmacological activities of trial drugs ${ }^{18}$

\begin{tabular}{|c|c|c|c|}
\hline Activity & Puskaramula & Kustha & Erandamula \\
\hline $\begin{array}{l}\text { Anti- } \\
\text { inflammatory } \\
\text { activity }\end{array}$ & $\begin{array}{c}\text { Extracts shown significant anti-inflamatory activity } \\
\text { against exodative phase of inflamation when tested } \\
\text { against carrageenin induced ratpaw oedema (Singh, N. } \\
\text { et al., 1976). }\end{array}$ & -- & $\begin{array}{l}\text { Root extract investigated against } \\
\text { carrageenin,5-hydroxytryptamine } \\
\text { (5HT)-, dextran-, bradykinin-and } \\
\text { prostaglandin E1 (PGE1)-induced rat } \\
\text { hind paw oedema. Extract ( } 0.15 \\
\text { g/kg) given orally } 2 \text { hr before } \\
\text { injection of above phlogistic agents } \\
\text { exhibited anti-inflammmatory } \\
\text { activity against all the agents except } \\
\text { PGE1; efficacy of extract was: } \\
\text { carrageenin > bradykinin > 5-HT > } \\
\text { dextran (Indian J.Pharmacol. 1990, } \\
\text { 22, 239). }\end{array}$ \\
\hline $\begin{array}{c}\text { Bronchodilatory } \\
\text { activity }\end{array}$ & $\begin{array}{l}\text { Alcoholic extract showed marked protective effect } \\
\text { against bronchospasm induced by histamina, } 5 \text {-HT, } \\
\text { Zea maize, Holaoptelia and Acacia arabice. The } \\
\text { extract blocked the contraction induced by both } \\
\text { histamine and } 5 \text {-HT and the response was graded in } \\
\text { nature }(50,100 \& 150 \mathrm{mg} / \mathrm{ml} \text { of the bath solution). } \\
\text { Inula has similar antispasmodic effect on rat uterus as } \\
\text { seen as guinea pig ileum. It blocked the response of } \\
\text { different doses }(0.05,0.1,0.2, \& 0.4 \mathrm{mg} / \mathrm{ml}) \text { of } 5-\mathrm{HT} \\
\text { in the dose range of } 50-200 \mathrm{mg} / \mathrm{ml} \text {. }\end{array}$ & $\begin{array}{l}\text { Delactonized oil and some } \\
\text { lactone fractions of the oil } \\
\text { exhibited spasmo-lytic and } \\
\text { broncho-dilatory effects } \\
\text { (Chopra, 1958; Dutta, 1960). }\end{array}$ & \\
\hline $\begin{array}{l}\text { Anti-histamine } \\
\text { activity }\end{array}$ & $\begin{array}{l}\text { The aqueous alcoholic extract of the roots was found } \\
\text { to have potent anti-5-HT- and antihistamine activities } \\
\text { as revealed by blockade of histamine - induced } \\
\text { contractions of isolated tracheal chain of guinea pig. } \\
\text { The drug also offered marked protection against } \\
\text { bronchospasm induced by histamine. 5-HT and } \\
\text { pollens of Zea maize, Holoptelia sp., and A.arabica in } \\
\text { guinea pigs. The beneficial effects of I.racemosa in } \\
\text { bronchial asthma appear to be due to its anti- } \\
\text { histaminic, anti-5-HT and antiallergic properties. }\end{array}$ & $\begin{array}{c}\text { Alkaloids from root have a } \\
\text { strong inhibitary effect on } \\
\text { histamine-induced } \\
\text { bronchospasm and intestinal } \\
\text { spasm in guinea pigs. } \\
\text { Chemical extracts from this } \\
\text { herb have antispasmodic, } \\
\text { bronchodilatery, and blood } \\
\text { pressure lowering effects } \\
\text { similar to, but weaker than } \\
\text { papaverine (Oxygen for life, } \\
\text { 1997). }\end{array}$ & -- \\
\hline
\end{tabular}

Table 2: Number of Male and Femald Subjects in the study

\begin{tabular}{|c|c|c|}
\hline & Male & Female \\
\hline Number & 46 & 44 \\
\hline Percentage & $51.11 \%$ & $48.89 \%$ \\
\hline
\end{tabular}

Table 3: Mean Age of Each group involved in the study

\begin{tabular}{|c|c|c|}
\hline Group & Avg age & SD \\
\hline Gr 1 & 39.43 & $(+) 13.85$ \\
\hline Gr 2 & 47.03 & $(+) 13.93$ \\
\hline Gr 3 & 43.57 & $(+) 14.60$ \\
\hline & $\mathbf{4 3 . 3 4}$ & $(+) 3.81$ \\
\hline
\end{tabular}


Table 4: Effect of kustha on IgE

\begin{tabular}{|c|c|c|}
\hline IgE & Present (\%) & Absent (\%) \\
\hline Before Treatment & $73.33(\mathrm{n}=22)$ & $26.67(\mathrm{n}=8)$ \\
\hline After Treatment & $26.67(\mathrm{n}=8)$ & $73.33(\mathrm{n}=22)$ \\
\hline
\end{tabular}

Table 6: Effect of puskaramula on AEC

\begin{tabular}{|c|c|c|}
\hline AEC & Present (\%) & Absent (\%) \\
\hline Before Treatment & $73.33(\mathrm{n}=22)$ & $26.67(\mathrm{n}=8)$ \\
\hline After Treatment & $36.67(\mathrm{n}=11)$ & $63.33(\mathrm{n}=19)$ \\
\hline
\end{tabular}

Table 8: Effect of erandamula on AEC

\begin{tabular}{|c|c|c|}
\hline AEC & Present (\%) & Absent (\%) \\
\hline Before Treatment & $73.33(\mathrm{n}=22)$ & $26.67(\mathrm{n}=8)$ \\
\hline After Treatment & $10(\mathrm{n}=3)$ & $90(\mathrm{n}=27)$ \\
\hline
\end{tabular}

Table 10: Effect of kustha on severity of asthmatic attack

\begin{tabular}{|c|c|c|c|}
\hline \multirow{2}{*}{ Asthmatic Attack } & \multicolumn{3}{|c|}{ Severity \% } \\
\cline { 2 - 4 } & Mild & Moderate & Severe \\
\hline Before Treatment & 23.33 & 63.33 & 13.33 \\
\hline After Treatment & 83.33 & 16.67 & 00 \\
\hline
\end{tabular}

Table 11: Effect of puskaramula on severity of asthmatic attack

\begin{tabular}{|c|c|c|c|}
\hline \multirow{2}{*}{ Asthmatic Attack } & \multicolumn{3}{|c|}{ Severity \% } \\
\cline { 2 - 4 } & Mild & Moderate & Severe \\
\hline Before Treatment & 26.67 & 53.33 & 20 \\
\hline After Treatment & 86.67 & 13.33 & 00 \\
\hline
\end{tabular}

Table 13: Reduction in usage of Inhalers etc in Group 1

\begin{tabular}{|c|c|c|}
\hline Use of Inhalers & Yes (\%) & No (\%) \\
\hline Before Treatment & 60 & 40 \\
\hline After Treatment & 23.33 & 76.67 \\
\hline
\end{tabular}

Table 14: Reduction in usage of Inhalers etc in Group 2

\begin{tabular}{|c|c|c|}
\hline Use of Inhalers & Yes (\%) & No (\%) \\
\hline Before Treatment & 66.67 & 33.33 \\
\hline After Treatment & 20 & 80 \\
\hline
\end{tabular}

Table 15: Reduction in usage of Inhalers etc in Group 3

\begin{tabular}{|c|c|c|}
\hline Use of Inhalers & Yes (\%) & No (\%) \\
\hline Before Treatment & 70 & 30 \\
\hline After Treatment & 16.67 & 83.33 \\
\hline
\end{tabular}

\section{Table 5: Effect of erandamula on IgE}

\begin{tabular}{|c|c|c|}
\hline IgE & Present (\%) & Absent (\%) \\
\hline Before Treatment & $63.33(\mathrm{n}=19)$ & $36.67(\mathrm{n}=11)$ \\
\hline After Treatment & $30(\mathrm{n}=9)$ & $70(\mathrm{n}=21)$ \\
\hline
\end{tabular}

Table 7: Effect of kustha on AEC

\begin{tabular}{|c|c|c|}
\hline AEC & Present (\%) & Absent (\%) \\
\hline Before Treatment & $63.33(\mathrm{n}=19)$ & $36.67(\mathrm{n}=8)$ \\
\hline After Treatment & $30(\mathrm{n}=9)$ & $70(\mathrm{n}=21)$ \\
\hline
\end{tabular}

Table 9: Effect of puskaramula on severity of asthmatic attack

\begin{tabular}{|c|c|c|c|}
\hline \multirow{2}{*}{ Asthmatic Attack } & Severity \% & \multicolumn{2}{|c|}{} \\
\cline { 2 - 4 } & Mild & Moderate & Severe \\
\hline Before Treatment & 20 & 60 & 20 \\
\hline After Treatment & 86.67 & 13.33 & 00 \\
\hline
\end{tabular}

Table 12: Spirometric evaluation of trial subjects

\begin{tabular}{|c|c|c|c|}
\hline Parameter & Group 1 & Group 2 & Group 3 \\
\hline FEV $_{\mathbf{1}}$ & & & \\
\hline Before treatment & $2.44+0.54$ & $2.27+0.38$ & $2.32+0.27$ \\
\hline After treatment & $2.43+0.53$ & $2.20+0.40$ & $2.29+0.28$ \\
\hline PEF & & & \\
\hline Before treatment & $6.54+1.38$ & $6.18+1.26$ & $6.28+1.26$ \\
\hline After treatment & $6.67+1.33$ & $6.26+1.32$ & $6.25+1.27$ \\
\hline FVC & & & \\
\hline Before treatment & $3.53+1.01$ & $3.56+1.31$ & $3.52+1.30$ \\
\hline After treatment & $3.24+0.77$ & $2.92+0.55$ & $2.98+0.53$ \\
\hline FEV /FVC $_{\text {Before treatment }}$ & $0.72+0.15$ & $0.70+0.18$ & $0.71+0.17$ \\
\hline After treatment & $0.76+0.08$ & $0.76+0.08$ & $0.75+0.07$ \\
\hline
\end{tabular}

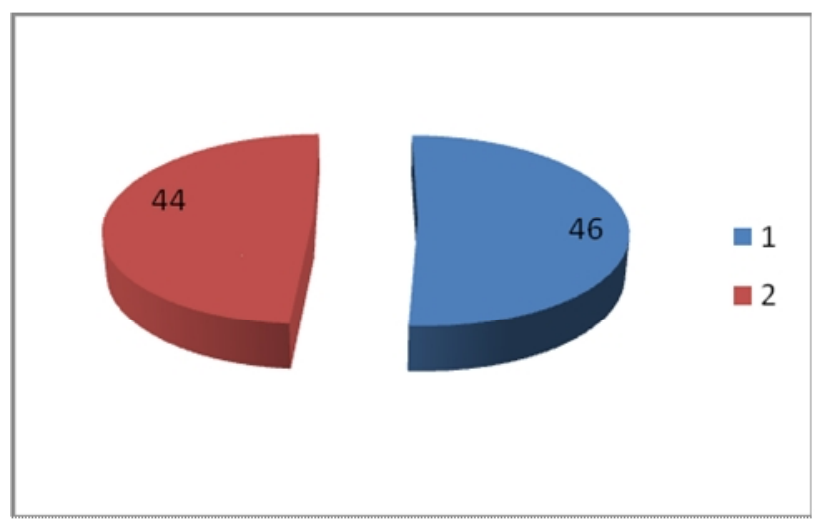

Chart 1: Number of male $\&$ female patients in the study

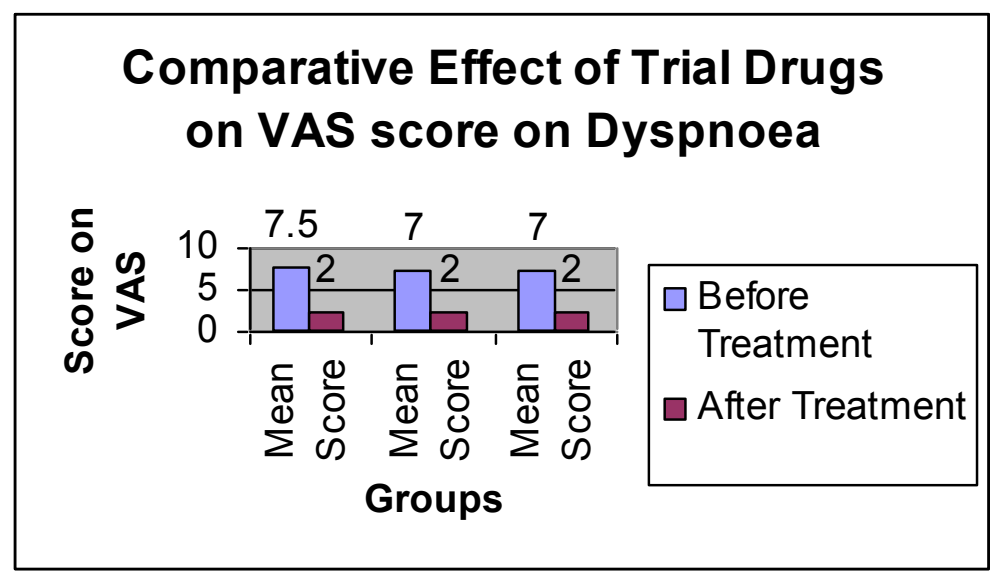

Chart 2 


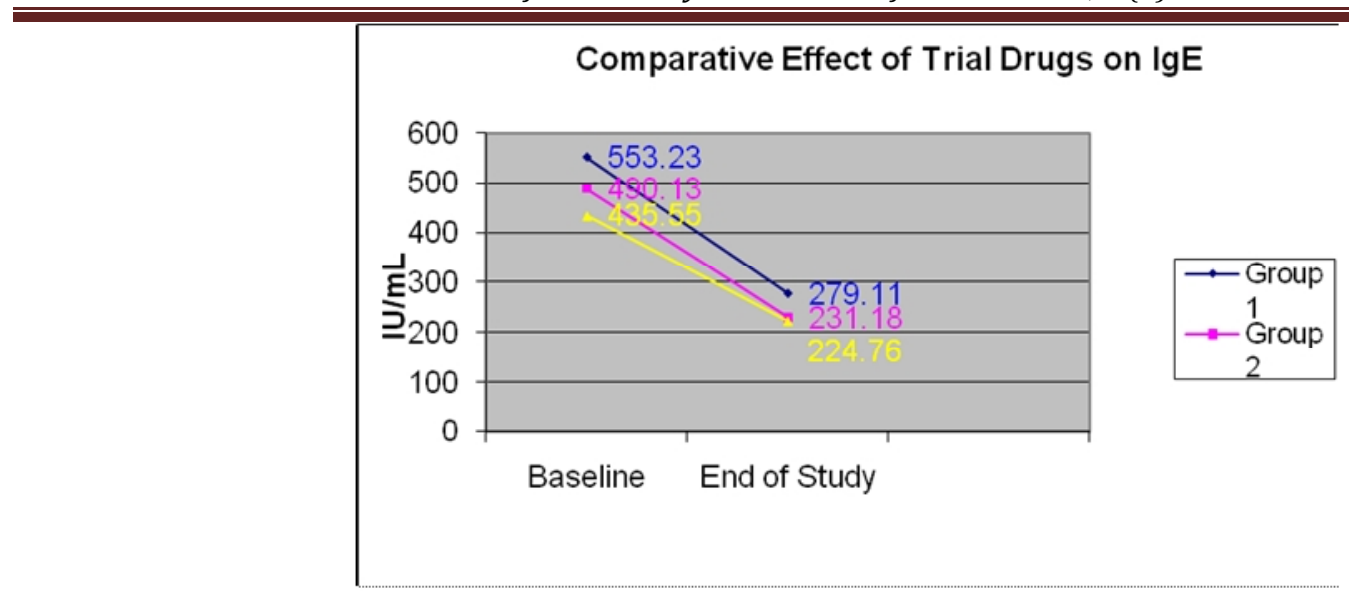

Chart 3

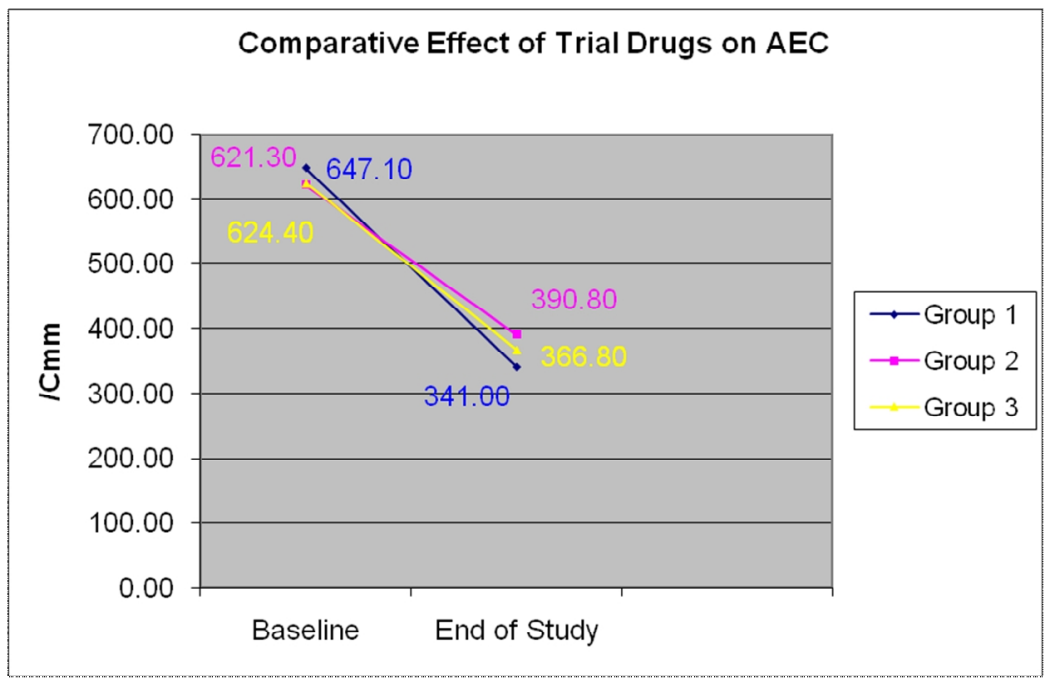

Chart 4

\section{RESULTS}

Total 105 subjects belonging to both sexes, between the age group of 16-65 years were recruited into the study through randamization chart 35 each into three groups (Group-1, Group-2 \& Group-3). Out of them, 90 subjects who completed the total study duration (3 months) 30 subjects in each group were finally assessed for understanding the comparative effect of the respective herbs in each group. There were 44 females and 46 males (vide Table $2 \&$ Chart $1)$. The mean age of the completed subjects $(n=90)$ is 43.34 years $(+3.81)$ - (vide Table 3$)$.

The mean age (both male and female together) of Group 1 is 39.43 years $(+13.85)$, while that of Group 2 is 47.03 years ( 13.93) and that of Group 3 is 43.57 years $(+14.60)$.

Out of 90 subjects in three groups together, there were 16, 14 and 16 male in Group 1, 2 and 3 respectively while female were 14, 16 and 14 respectively in Group 1,2 and 3. The mean age of male subjects in Group 1 is 36.69 years $(+$ 14.86) while that in Group 2 is 45.57 years $(+15.24)$ and that in Group 3 is 39.38 years $(+14.66)$. The mean age of female subjects in Group 1 is 42.57 years $(+9.79)$ while that in Group 2 is 47.50 years $(+13.75)$ and that in Group 3 is 46.71 years $(+13.12)$.
Comparative Effect of Trial Drugs on Symptoms of Bronchial Asthma

\section{Dyspnoea (breathlessness)}

Dyspnoea was present in $90 \%(\mathrm{n}=27)$ of subjects in Group 1 at the baseline. After 12 weeks of drug administration the presence of dyspnoea was reduced and found to be present in $26.67 \%(n=8)$ of subjects. But severity of symptom is considerably reduced in all the subjects who were administered with the interventional drug.

Dyspnoea was present in $86.67 \%(\mathrm{n}=26)$ of subjects in Group 2 at the baseline. After 12 weeks of drug administration the presence of dyspnoea was reduced and found to be present in $20 \%(n=6)$ of subjects. But severity of symptom is considerably reduced in all the subjects who were administered with Puskaramula.

Dyspnoea was present in $93.33 \%(n=27)$ of subjects in Group 3 at the baseline. After 12 weeks of drug administration the presence of dyspnoea was reduced and found to be present in 23.33\% $(n=7)$ of subjects. But severity of symptom is considerably reduced in all the subjects who were administered with kustha.

\section{Scoring of Dyspnoea on VAS}

When the severity of Dyspnoea was scored over a 10 points Visual Analogue Scale, It was found that at baseline the mean score was $7(+1.37)$, which was reduced to $2(+1.10)$ after administration of trial drug in group-1 for 12 weeks. The 
reduction in the severity was found to be statistically significant $(\mathrm{p}<0.001)$.

When the severity of Dyspnoea was scored over a 10 points Visual Analogue Scale, It was found that at baseline the mean score was $7(+1.33)$, which was reduced to $2(+1.10)$ after administration of trial drug in group- 2 for 12 weeks. The reduction in the severity was found to be statistically significant $(p<0.001)$ in all the three groups.

When the severity of Dyspnoea was scored over a 10 points Visual Analogue Scale, It was found that at baseline the mean score was $7(+1.33)$, which was reduced to $2(+1.10)$ after administration of trial drug in group-3 for 12 weeks. The reduction in the severity was found to be statistically significant $(p<0.001)$ in all the three groups.

There is a significant change between the baseline mean score and VAS score at the end of the study in each group ( $p$ $<0.001$ ). However, the VAS score does not show significant variation when a comparison is made between the three groups $(p>0.01)$. That means there was intra group significance but not inter group significance. Almost all the groups showed comparable efficacy on dyspnoea. The details are present in Chart 2.

\section{Cough}

Cough was present in $80 \%(n=24)$ of subjects in Group 1 at the baseline. After 12 weeks of drug administration the presence of dyspnoea was reduced and found to be present in $13.33 \%(n=4)$ of subjects. But severity of symptom is considerably reduced in all the subjects who were administered with the interventional drug.

Cough was present in $73.33 \%(n=22)$ of subjects in Group 2 at the baseline. After 12 weeks of drug administration the presence of dyspnoea was reduced and found to be present in $10 \%(\mathrm{n}=3)$ of subjects. But severity of symptom is considerably reduced in all the subjects who were administered with the interventional drug.

Cough was present in $70 \%(n=21)$ of subjects in Group 3 at the baseline. After 12 weeks of drug administration the presence of dyspnoea was reduced and found to be present in $10 \%(\mathrm{n}=3)$ of subjects. But severity of symptom is considerably reduced in all the subjects who were administered with the interventional drug.

The percentage of relief from cough in three groups is statistically as well as clinically significant when comparison is made between baseline and end of the study $(\mathrm{p}<0.001$ in each group). However, there was no significant difference between the groups in percentage of relief $(p>0.05)$ showing that all the three interventional drugs have similar effect or comparable effect.

\section{Wheezing}

Wheezing was present in $90 \%(n=27)$ of subjects in Group $\mathbf{1}$ at the baseline. After 12 weeks of drug administration the presence of dyspnoea was reduced and found to be present in $26.67 \%(\mathrm{n}=8)$ of subjects. But severity of symptom is considerably reduced in all the subjects who were administered with the interventional drug.

Wheezing was present in $86.67 \%(\mathrm{n}=26)$ of subjects in Group 2 at the baseline. After 12 weeks of drug administration the presence of dyspnoea was reduced and found to be present in 20\% $(n=6)$ of subjects (Vide Table 15). But severity of symptom is considerably reduced in all the subjects who were administered with Puskaramula.

Wheezing was present in $93.33 \%(\mathrm{n}=27)$ of subjects in Group 3 at the baseline. After 12 weeks of drug administration the presence of dyspnoea was reduced and found to be present in $23.33 \%(n=7)$ of subjects. But severity of symptom is considerably reduced in all subjects who were administered with kustha.

The percentage of relief from wheezing in three groups is statistically as well as clinically significant when comparison is made between baseline and end of the study $(p<0.001$ in each group). However, the difference between the groups in percentage of relief is non significant $(p>0.05)$ showing that all the three interventional drugs have similar effect or comparable effect.

\section{Effect of trial drugs on Serum IgE}

Serum IgE was found elevated in $53.33 \%(n=16)$ of subjects in Group 1 at the baseline. After 12 weeks of drug administration the IgE levels were found elevated in $33.33 \%$ $(\mathrm{n}=10)$ of subjects. The mean average of serum $\mathrm{IgE}$ at baseline and end of the study was found to be 553.23 (+ 215.51) IU/mL and $279.11(+188.97) \mathrm{IU} / \mathrm{mL}$ respectively (p $<0.001)$.

Serum IgE was found elevated in $73.33 \%(n=22)$ of subjects in Group 2 at the baseline. After 12 weeks of drug administration the IgE levels were found elevated in $26.67 \%$ $(\mathrm{n}=8)$ of subjects (Vide Table 4). The mean average of serum $\operatorname{IgE}$ at baseline and end of the study was found to be $490.13(+221.4) \mathrm{IU} / \mathrm{mL}$ and $231.19(+121.54) \mathrm{IU} / \mathrm{mL}$ respectively $(\mathrm{p}<0.001)$.

Serum IgE was found elevated in $63.33 \%(n=19)$ of subjects in Group 3 at the baseline. After 12 weeks of drug administration the IgE levels were found elevated in $30 \%$ (n $=9$ ) of subjects (Vide Table 5). The mean average of serum $\operatorname{IgE}$ at baseline and end of the study was found to be 435.55 $(+270.48) \mathrm{IU} / \mathrm{mL}$ and $224.76(+159.88) \mathrm{IU} / \mathrm{mL}$ respectively $(\mathrm{p}<0.001)$.

The mean reduction of $\mathrm{IgE}$ in all the three groups is statistically as well as clinically significant when comparison made between the values at baseline and at end of the study $(p<0.001$ in each group). However, there was no significant difference between the groups in percentage of relief $(p>$ 0.05 ) showing that all the three interventional drugs have similar or comparable effect Vide: Chart 3).

\section{Effect of trial drugs on AEC}

The AEC was found elevated in $73.33 \%(n=22)$ of subjects in Group 1 at the baseline. After 12 weeks of drug administration, the AEC was found elevated in $36.67 \%(\mathrm{n}=$ 11) of subjects (Vide Table 6). The mean average of AEC at baseline and end of the study was found to be $647.10(+176)$ $/ \mathrm{Cmm}$ and $341.00(+100) / \mathrm{Cmm}$ respectively $(\mathrm{p}<0.001)$.

The AEC was found elevated in $63.33 \%(n=19)$ of subjects in Group 2 at the baseline. After 12 weeks of drug administration, the AEC was found elevated in $30 \%(n=9)$ of subjects (Vide Table 7). The mean average of AEC at baseline and end of the study was found to be $621.30(+173)$ $/ \mathrm{Cmm}$ and $390.80(+186) / \mathrm{Cmm}$ respectively $(\mathrm{p}<0.001)$.

The AEC was found elevated in $73.33 \%(n=22)$ of subjects in Group 3 at the baseline. After 12 weeks of drug administration, the AEC was found elevated in $30 \%(n=9)$ of subjects (Vide Table 8). The mean average of AEC at baseline and end of the study was found to be $624.40(+161)$ $/ \mathrm{Cmm}$ and $366.80(+198) / \mathrm{Cmm}$ respectively $(\mathrm{p}<0.001)$.

The mean reduction of AEC in all the three groups is statistically as well as clinically significant when comparison made between the values at baseline and at end of the study $(p<0.001$ in each group). However, there was no significant 
difference between the groups in percentage of relief $(p>$ 0.05 ) showing that all the three interventional drugs have similar or comparable effect Vide: Chart 4).

\section{Severity of Asthmatic Attack}

Out of 30 enrolled subjects in Group 1, 20\% $(n=6)$ had history of severe asthmatic attacks, $60 \%(\mathrm{n}=18)$ reported moderate attacks and rest $20 \%(n=6)$ reported presence of mild asthmatic attacks at baseline. After administration of Puskaramula for twelve weeks it was observed that in $86.67 \%(\mathrm{n}=26)$ subjects the severity was mild and in rest $13.33 \%(n=4)$ severity was moderate. No subject reported severe asthmatic attack. The details are given in table 9 .

Out of 30 enrolled subjects in Group 2, 23.33\% $(n=7)$ had history of severe asthmatic attacks, $63.33 \%(\mathrm{n}=19)$ reported moderate attacks and rest $13.33 \%(n=4)$ reported presence of mild asthmatic attacks at baseline. After administration of Kustha for twelve weeks it was observed that in $86.67 \%(\mathrm{n}=$ $25)$ subjects the severity was mild and in rest $13.33 \%(n=4)$ severity was moderate. No subject reported severe asthmatic attack. The details are given in table 10 .

Out of 30 enrolled subjects in Group 3, 26.67\% $(n=8)$ had history of severe asthmatic attacks, $53.33 \%(n=16)$ reported moderate attacks and rest $20 \%(\mathrm{n}=6)$ reported presence of mild asthmatic attacks at baseline. After administration of Erandamula for twelve weeks it was observed that in $86.67 \%$ $(\mathrm{n}=26)$ subjects the severity was mild and in rest $13.33 \%(\mathrm{n}$ $=4)$ severity was moderate. No subject reported severe asthmatic attack. The details are given in table 11 .

The percentage of relief from severity of asthmatic attack in all the three groups is statistically as well as clinically significant when comparison is made between baseline and end of the study ( $p<0.001$ in each group). However, the difference between the groups in percentage of relief is non significant $(\mathrm{p}>0.05)$ showing that all the three interventional drugs have similar effect or comparable effect.

\section{Effect of the trial drug on Spirometric parameters}

Spirometry was performed for all the subjects recruited into the trial both at the baseline and at the end of the study (i.e., after 12 weeks) using 12 parameter MicroLabs spirometer. It is observed that the $\mathrm{FEV}_{1}$ in group 1, $\mathbf{2}$ and $\mathbf{3}$ is respectively $2.44+0.54 ; 2.27+0.38$ and $2.32+0.27$ at the baseline. The same at the end of the study is $2.43+0.53 ; 2.20+0.40$ and $2.29+0.28$ in group $\mathbf{1 ,} \mathbf{2}$ and $\mathbf{3}$ respectively.

The PEF reading in group 1, 2 and $\mathbf{3}$ is respectively $6.54+$ $1.38 ; 6.18+1.26$ and $6.28+1.26$ at the baseline. The same at the end of the study is $6.67+1.33 ; 6.26+1.32$ and $6.25+$ 1.27 in group 1, $\mathbf{2}$ and $\mathbf{3}$ respectively.

FVC in group 1, $\mathbf{2}$ and $\mathbf{3}$ are respectively $3.53+1.01 ; 3.56+$ 1.31 and $3.52+1.30$ at the baseline. The same at the end of the study is $3.24+0.77 ; 2.92+0.55$ and $2.98+0.53$ in group 1, 2 and 3 respectively (Vide : Table No. 12).

The \% reduction of FEV1 and PEF in the trial subjects is comparable in each group. But the variation between the groups is statistically not significant $(p>0.05)$.

\section{Use of Inhaler}

It was observed that $60 \%$ subjects $(n=18)$ in Group 1 were using inhalers/oral medication at baseline. At the end of study this percentage came down to $23.33 \%(\mathrm{n}=7)$ (Vide: Table 13).

It was observed that $66.67 \%$ subjects $(n=20)$ in Group 2 were using inhalers/oral medication at baseline. At the end of study this percentage came down to $20 \%(\mathrm{n}=6)$ (Vide: Table 14).

It was observed that $70 \%$ subjects $(\mathrm{n}=21)$ in Group 3 were using inhalers/oral medication at baseline. At the end of study this percentage came down to $16.67 \%(\mathrm{n}=5)$ (Vide Table 15).

\section{RESULTS}

Evaluation of the observations on the basis of the obtained results indicate that there is clinical as well as statistical significance $(p<0.001)$ in the improvement observed in symptoms i.e. dyspnoea, wheezing and cough during the study in each group. The relief percentage is comparable between three groups i.e., statistically non-significant ( $p>$ $0.05)$.

There is statistically highly significant change observed in reduction of VAS scores of dyspnoea $(p<0.001)$ in each group, thereby inferring that dyspnoea in Bronchial Asthma can be controlled to a great extent by administering all the three interventional drugs. Their therapeutic benefit is comparable.

The IgE reducing effect of Puskaramula, Kustha and Erandamula churna are found to be comparable $(p<0.05)$. Serum $\operatorname{IgE}$ was found elevated in $53.33 \%(n=16)$ of subjects in Group 1 at the baseline. After 12 weeks of drug administration the IgE levels were found elevated in 33.33\% $(n=10)$ of subjects. The mean average of serum $\operatorname{IgE}$ at baseline and end of the study was found to be 553.23 (+ $215.51) \mathrm{IU} / \mathrm{mL}$ and $279.11(+188.97) \mathrm{IU} / \mathrm{mL}$ respectively (p $<0.05)$. Serum $\operatorname{IgE}$ was found elevated in $73.33 \%(\mathrm{n}=22)$ of subjects in Group 2 at the baseline. After 12 weeks of drug administration the $\operatorname{IgE}$ levels were found elevated in $26.67 \%(n=8)$ of subjects. The mean average of serum IgE at baseline and end of the study was found to be 490.13 (+ 221.4) $\mathrm{IU} / \mathrm{mL}$ and $231.19(+121.54) \mathrm{IU} / \mathrm{mL}$ respectively $(\mathrm{p}<$ $0.05)$. Serum IgE was found elevated in $63.33 \%(\mathrm{n}=19)$ of subjects in Group 3 at the baseline. After 12 weeks of drug administration the IgE levels were found elevated in 30\% (n $=9$ ) of subjects). The mean average of serum IgE at baseline and end of the study was found to be $435.55(+270.48)$ $\mathrm{IU} / \mathrm{mL}$ and $224.76(+159.88) \mathrm{IU} / \mathrm{mL}$ respectively $(\mathrm{p}>0.05)$. The AEC was elevated in $73.33 \%(n=22), 63.33 \%(n=19)$ \& $73.33 \%(n=22)$ of subjects in Group 1, 2 \& 3 respectively at the baseline. After 12 weeks of drug administration, the AEC was elevated only in $36.67 \%(\mathrm{n}=$ $11), 30 \%(n=9) \& 30 \%(n=9)$ of subjects. The mean average of AEC at baseline was found to be $647.10(+176)$ $/ \mathrm{Cmm}, 621.30(+173) / \mathrm{Cmm} \& 624.40(+161) / \mathrm{Cmm}$ respectively in Group $1,2 \& 3$ respectively. The same is found to be $341.00(+100) / \mathrm{Cmm}, 390.80(+186) \& 366.80$ $(+198) / \mathrm{Cmm}$ respectively at the end of the study in Group 1, $2 \& 3$.

The mean reduction of AEC in all the three groups is statistically as well as clinically significant when comparison made between the values at baseline and at end of the study $(p<0.001$ in each group). However, there was no significant difference between the groups in percentage of relief $(p>$ 0.05 ) showing that the interventional drugs have comparable effect

The daily dose of consumption of oral bronchodilators as well as other inhalers has come down significantly i.e., about $60 \%$ subjects $(\mathrm{n}=18)$ in Group 1 who were using inhalers/oral medication at baseline have come down to $23.33 \%(\mathrm{n}=7)$ at the end of the study; about $66.67 \%$ subjects $(n=20)$ in Group 2 who were using inhalers/oral medication at baseline have come down to $20 \%(\mathrm{n}=6)$; and about $70 \%$ subjects $(\mathrm{n}=21)$ 
in Group 3 who were using inhalers/oral medication at baseline have come down to $16.67 \%(\mathrm{n}=5)$.

There is a significant reduction in the severity of Asthma attacks after the use of trial medicines in all the three groups. Out of 30 enrolled subjects in Group 1, 20\% $(\mathrm{n}=6), 60 \%(\mathrm{n}$ $=18)$ and $20 \%(\mathrm{n}=6)$ reported presence of severe, moderate and mild asthmatic attacks respectively at baseline. After administration of Puskaramula for twelve weeks in $86.67 \%$ (n $=26)$ subjects the severity was mild and in rest $13.33 \%(\mathrm{n}=$ 4) severity was moderate while, no subject reported with severe attack. Out of 30 enrolled subjects in Group 2, $23.33 \%(n=7), 63.33 \%(n=19)$ and $13.33 \%(n=4)$ reported presence of severe, moderate and mild asthmatic attacks respectively at baseline. After administration of Kustha for twelve weeks in $86.67 \%(\mathrm{n}=25)$ subjects the severity was mild and in rest $13.33 \%(n=4)$ severity was moderate while no subject reported with severe asthmatic attack. Out of 30 enrolled subjects in Group 3, 26.67\% ( $\mathrm{n}=8), 53.33 \%(\mathrm{n}=$ 16) and $20 \%(\mathrm{n}=6)$ reported presence of severe, moderate and mild asthmatic attacks respectively at baseline. After administration of Erandamula for twelve weeks in $86.67 \%$ (n $=26)$ subjects the severity was mild and in rest $13.33 \%(\mathrm{n}=$ 4) severity was moderate while no subject reported with severe attack.

All the trial drugs were found to be safe. No adverse drug reactions/ side effects of what so ever nature were observed in any of the subjects during the course of trial.

Therefore, it can be concluded on the basis of above findings that all the three trial drugs were equally effective in reducing the signs and symptoms of chronic bronchial asthma and has the capacity to reduce the dosage of oral medication as well as inhalers to a great extent $(>60 \%)$. The relief percentage within the groups is statistically highly significant $(p<0.001)$ while the same between the groups is non-significant $(p>$ 0.05 ). Therefore it is concluded that all the three trial drugs are equally potential in reducing the symptoms of asthma.

\section{Safety Profile}

No significant change was observed in haemogram, Liver function tests (L.F.T.) and Renal function tests (R.F.T.) of any subject, carried out at baseline and after the treatment with trial drug $(p>0.05)$.

\section{Adverse Drug Reactions (ADRs)}

None of the subjects have reported with any major ADRs except nausea and vomiting in less than $1 \%$ of the subjects. Even these subjects attributed the symptoms to the bitter tatse of Puskaramula and Kustha.

\section{Drop outs \& Early Withdrawal}

There were two drop outs in group 1 and three each in group 2 and 3. But, these were noted to be due to personal reasons, not treatment related. None of the subjects withdrawn from study due to any adverse drug reaction or adverse event during the course of treatment with trial drug.

\section{DISCUSSION}

In the present study it is attempted to understand the rationality behind the concept of substitutes as menitoned in the ayurvedic texts. The study reveals statistically highly significant change in reduction of VAS scores of dyspnoea, cough and wheezing $(\mathrm{p}<0.001)$ in group $1 \& 2$, confirming such observation made by earlier observers on Puskaramula and Kustha. The results in the group 3 are also comparable to group 1 \& 2 indicating the anti-asthmatic effect of
Erandamula for the first time. This effect is attributed to the unidentified tri-terpinoids present in the root of $R$. communis. All the three trial herbs have exhibited comparable results on IgE reduction $(p<0.05)$. The mean reduction of AEC in all the three groups is statistically as well as clinically significant when comparison made between the values at baseline and at end of the study ( $p<0.001$ in each group). However, there was no significant difference between the groups in percentage of relief $(p>0.05)$ showing that all the three interventional drugs have comparable effect.

The daily dose of consumption of oral bronchodilators as well as other inhalers has come down significantly in all the groups indicating that the trial drugs have comparable effects owing to the tri-terpenoids commonly present in all the three herbs. Similar studies on other substitutes will provide substantial information on the Abhavapratinidhi dravyas on the scientific basis.

\section{CONCLUSION}

The trial herbs (Pushkarmula / PM, Kushta / KS and Erandamula / EM) in the form of powder administered at the dose of $2 \mathrm{~g}$ twice daily with honey to the subjects suffering from Tamakaswasa / Bronchial Asthma showed comparable efficacy both statistically as well as clinically $(p>0.05)$ justifying the substitute status.

Kustha (Sausurea lappa) root exhibited morphological, chemical and therapeutic similarity as a substitute for Puskaramula (Inula racemosa) whereas Erandamula (Ricinus communis) exhibited only therapeutic similarity as a substitute for Puskaramula.

The study proves the value of the fundamental concepts of Ayurveda. For example, doshapratyanika cikitsa stands proven in this context of Erandamula as the substitute to Puskaramula while, vyadhipratyanika cikitsa is the case with Kustha as the substutue to Puskramula.

\section{REFERENCES}

1. Sastry J.LN. ; Data-base on Substitutes used in Ayurveda. RAV Souvenir - p.23-27. 2010.

2. Sastry J.L.N.; Identification of Market Samples of Pushkaramula and Kustha - an experimental study. P.G. Dissertation, Dept. of Dravyaguna, Dr.B.R.K.R.Govt. Ayu.College, Hyderabad. 1995-98.

3. Aggarwal P., et. al. Efficacy of Nebulised Ipratropium in Acute Bronchial Asthma. Journal Indian Academy of Clinical Medicine Vol. $3 \&$ 4. 2002.

4. Alfred Goodman \& Gillman; The Phamrmacological basis of Theraoeutics. New York : Maxwell International Edition. 1996.

5. Anonymous : Ayurvedic Pharacopoea of India. New Delhi : Govt. of India. 2001.

6. Anonymous : Bhavapraksa. Varanasi : Chaukhambha Sanskrit Sansthan. 1961.

7. Anonymous : Caraka Samhita. Varanasi : Chaukhambha Bharati Academy. 1996.

8. Bapalal Vaidya; Some controversial Drugs in Indian Medicine. Varanasi : Chaukhambha Orientalia. 1986.

9. Chunekar K.C. \& Pandey J.S., Bhava Prakasa Nighantu. Varanasi : Choukhambha Orientalia. 1984.

10. Dattaram Cahube; Brhannighanturatnakar. Bombay : Khemraj Shrikrishandas Prakashan. 1995.

11. Harrison's Principles of Internal Medicine, $15^{\text {th }}$ ed. Pub. Mc Graw Hill. 2001.

12. http://www.who.int/mediacentre/factsheets/fs206/en/print.html (Dt. 23.05.2006)

13. Ian R. Mackey, and Fred S. Rosen, (Edi) Asthma; William W. Busse, \& Robert F. Lemanske, $\mathrm{J}_{\mathrm{R} .}$, Advances in Immunology. N E J M, Vol. 344, No.5 . Feb. 1, 2001.

14. Juniper E. F. et. al. How Should we Quantify Asthma Control? (Chest. 2004;125:93-97) Measuring Health-Related Quality of Life in Adults During an Acute Asthma Exacerbation* Chest. 2002.

15. Juniper E.F. et.al.; Development and validation of the Mini Asthma Quality of Life Questionnaire. Eur Respir J., 14:32-38, 1999. 
16. Lipworth BJ.; Clinical pharmacology of corticosteroids in bronchial asthma. Pharmacol Ther; 58: 173-209. 1993.

17. Rastogi R.P. \& Merhotra B.N., Compendium of Indian Medicinal Plants Vol.I, II, III, IV, V \& VI. New Delhi : SCIR, 1995, 1993, 1993, $1996,1997 \& 1999$.

18. Sastry J.L.N.; Identification of Market Samples of Pushkaramula and Kustha - an experimental study. P.G. Dissertation, Dept. of Dravyaguna, Dr.B.R.K.R.Govt. Ayu.College, Hyderabad. 1998.

19. Sastry J.L.N.; Ayurvedokta Oushadha Niruktamala. Varanasi : Chaukhambha Orientalia. 2000.

20. Sastry J.L.N.; Dravyaguna Vijananam Vol. II. Varanasi : Chaukhambha Orientalia, 2002.

21. Sastry J.L.N.; Madanapala Nighantu (with English Commentary). Varanasi : Chaukhambha Orientalia, 2010.

22. Satoshkar R.S. \& Bhandarkar S.D. ; Pharmacology and Pharmacotherapeutics. Mumbai : Popular Prakashan, 1998.
23. Satyavathi G.V. et al., Medicinal Plants of India. Vo.I. New Delhi : ICMR, 1974.

24. Satyavathi G.V. et al., Medicinal Plants of India. Vo.II. New Delhi : ICMR, 1987.

25. Sharma P.C. et al.; Database on Medicinal Plants Used in Ayurveda. Vol. 1-7. New Delhi : CCRAS. 2005-2009.

26. Sharma P.V.; Dravya Guna Vijnana Vol. I \& IV. Varanasi : Chaukhambha Series.1983.

27. Shaik Aleem, Erandamulam Vrsyanam. P. G. Dept of K.C., Govt. College of Indian Medicine, Mysore. 1993.

\section{Cite this article as:}

J. L. N. Sastry, Tanuja M. Nesari, Huparikar Rajendra. Comparative study on the substitutes used in Ayurveda with special reference to substitutes for Pushkaramula (Inula racemosa Hook.F.) viz., Kushta (Saussurea lappa Decne.) and Erandamula (Ricinus communis L.): A clinical study. Int. Res. J. Pharm. 2013; 4(5):92-100 